\title{
Total deglovement of the fourth digit due to ring avulsion injury
}

\author{
Willem-Maarten Bosman, Frederik J Prakken, Ewan D Ritchie
}

Department of Surgery, Rijnland Ziekenhuis, Leiderdorp, The Netherlands

\section{Correspondence to} Dr Ewan Ritchie; e.ritchie@rijnland.nl
To cite: Bosman WM Prakken FJ, Ritchie ED. BMJ Case Rep Published online: [please include Day Month Year] doi:10.1136/bcr-2013200866

\section{DESCRIPTION}

A 59-year-old man presented to the emergency department after injuring the fourth digit of his right hand in an attempt to pick up a key on the other side of a steel rod fence. While leaning over the fence, he lost his balance, leading to a fall while his wedding ring got stuck on one of the rods of the fence. The ring subsequently degloved the skin and subcutis from the finger.

Physical examination showed a total deglovement injury up to the base of the proximal phalanx (figure 1). The flexor and extensor tendons were totally exposed but remained functional (Kay grade IV). ${ }^{1}$ The degloved skin was brought along with the patient, but was completely avital (figure 2). The plastic surgeon on call was consulted, but saw no reconstructive options. The degloved finger was amputated at metacarpal level.

Ring avulsion injury is a rare injury, which often leads to amputation of the involved finger. ${ }^{1}{ }^{2}$ In most cases it involves the fourth digit of the hand, also known as 'the ringfinger'. The mechanism inflicts both longitudinal traction and crush/degloving injury to the finger. The longitudinal traction causes occult injury to blood vessels beyond those injuries that are visible with the operating microscope. ${ }^{2}$

In specialised centres with microscopic surgery experience, an attempt to replantation and revascularisation of the degloved skin is possible with varying success (ie, secondary necrosis, cellulitis,

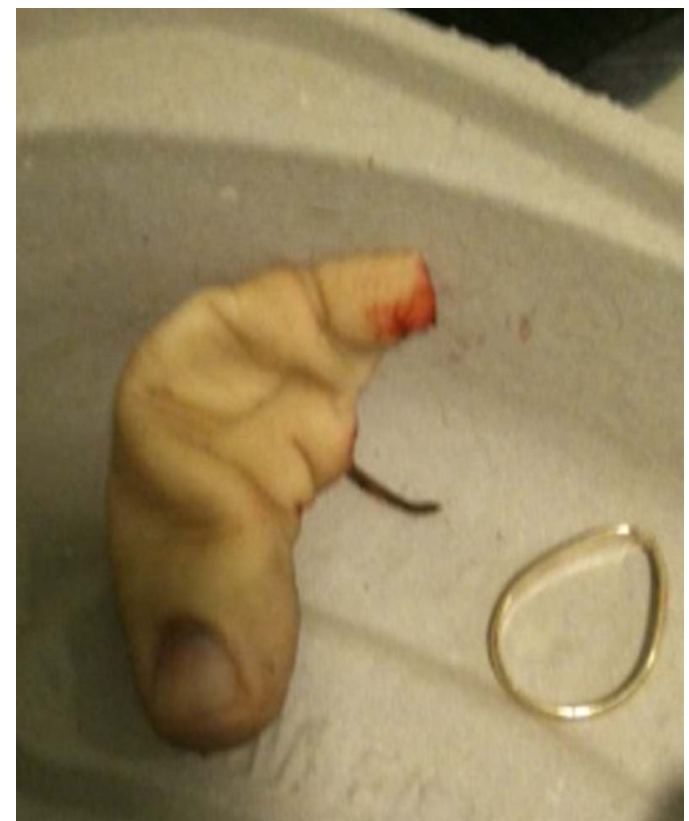

Figure 2 Avital skin defect and the 'corpus delicti'.

oedema, rigid finger, and hypoesthesia). ${ }^{2}{ }^{3}$ Other treatment modalities are free flap transplantations (in case of more involved fingers), venous flowthrough flap transpositions or in case of segmental injuries (Kay grades I-III) skin transplantations. ${ }^{2}$

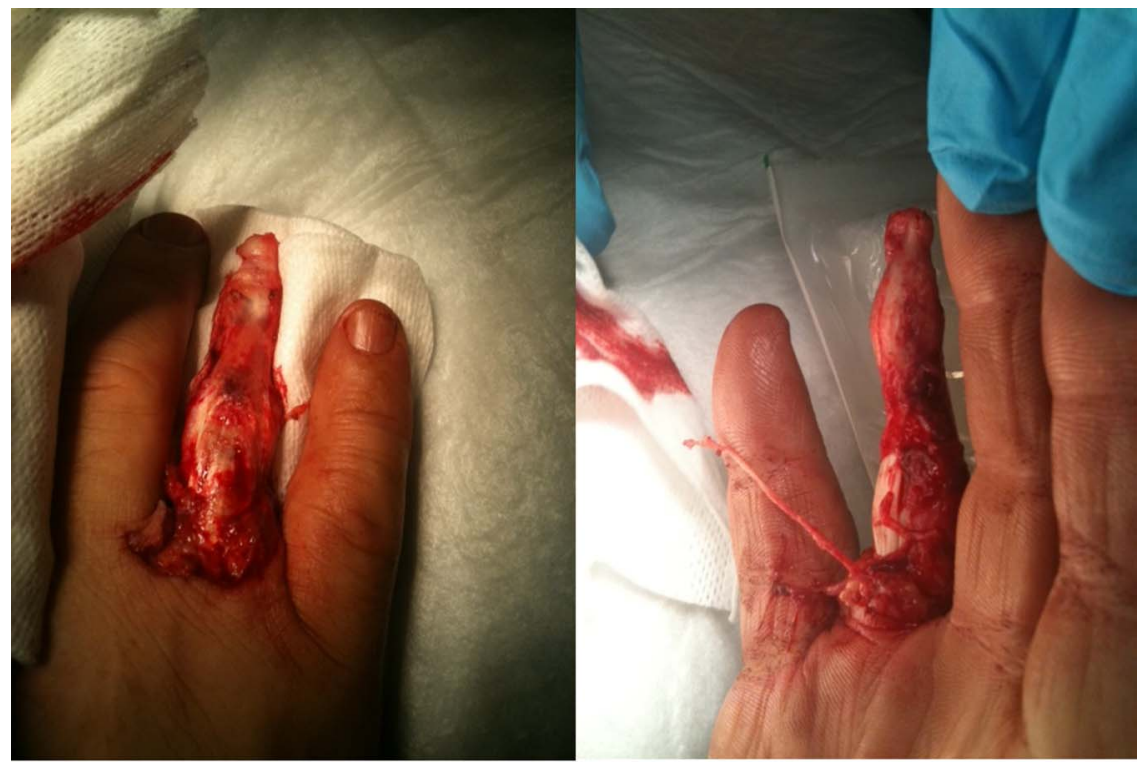

Figure 1 Total deglovement injury of the fourth digit, reaching to the base of the proximal phalanx after a ring avulsion. 


\section{Learning points}

- Wearing a ring may lead to serious deglovement injuries and subsequent amputation of the involved finger.

- Reconstructive options are possible in experienced centres but have varying success rates.

- The mechanism inflicts both longitudinal traction and crush/ degloving injury to the finger.
Competing interests None.

Patient consent Obtained.

Provenance and peer review Not commissioned; externally peer reviewed.

\section{REFERENCES}

1 Kay S, Werntz J, Wolff TW. Ring avulsion injuries: classification and prognosis. YJHSU 1989;14(2 Pt 1):204-13.

2 Brooks D, Buntic RF, Kind GM, et al. Ring avulsion: injury pattern, treatment, and outcome. Clin Plas Surg 2007:34:187-95.

3 Adani R, Marcoccio I, Castagnetti C, et al. Long-term results of replantation for complete ring avulsion amputations. Ann Plast Surg 2003;51:564-8.

Contributors WMB was involved in primary survey, drafting article, literature search, overall responsible. FJP was involved in performed operation, review of article. EDR was involved in performed operation, review of article.

Copyright 2013 BMJ Publishing Group. All rights reserved. For permission to reuse any of this content visit http://group.bmj.com/group/rights-licensing/permissions.

BMJ Case Report Fellows may re-use this article for personal use and teaching without any further permission.

Become a Fellow of BMJ Case Reports today and you can:

- Submit as many cases as you like

- Enjoy fast sympathetic peer review and rapid publication of accepted articles

- Access all the published articles

- Re-use any of the published material for personal use and teaching without further permission

For information on Institutional Fellowships contact consortiasales@bmjgroup.com

Visit casereports.bmj.com for more articles like this and to become a Fellow 